\title{
Questioning the Location of the Old Kingdom Capital of Memphis, Egypt
}

\author{
Serena Love \\ Department of Cultural and Social Anthropology, Stanford University
}

\begin{abstract}
The capital city of Memphis was ancient Egypt's oldest and largest city. However, the city's origin is shrouded in myth. This study challenges five different references to Memphis, from both classical and historical accounts and concludes that Memphis' boundary should be redefined. These accounts are reviewed to illustrate the confusion amongst early historians and travellers as to the precise location of Memphis and to highlight the association between the capital and the pyramids of the Giza Plateau. For the Old Kingdom, the urban limits of Memphis should not be restricted to the modern mound of Mit Rahina, but rather the boundaries should be expanded to parallel the Old Kingdom pyramids. Recent archaeological investigations, employing sub-surface sampling techniques, have revealed contemporary Old Kingdom occupational debris scattered throughout the entire Memphite region. The inclusion of archaeological material, in combination with the historical records, will create a different interpretation for Egypt's Old Kingdom capital city.
\end{abstract}

\section{Introduction}

Memphis has typically been regarded as the capital city for most of ancient Egypt's Dynastic period. It was located in Lower Egypt, at the apex of the Nile Delta. According to Egyptian myths and classical legends, the first king of Egypt established the city, $c .3100$ BC. Since the Early Dynastic period, Memphis was believed to be the home of the kings, the centre of state administration and sacred to the gods. The surviving remains of Memphis, around the modern town of Mit Rahina, are found within a six square kilometre area (Jeffreys 2000). Scant archaeological remains for early Memphis cast doubts about the creation and boundaries of the city. This investigation demonstrates how the ideas concerning Memphis are determined by the presence of later materials and historical references, which falsely presume continuity in the use of space for early Memphis.

Contemporary occupational material from the Old Kingdom has been found scattered throughout the Memphite area, challenging the size and shape of the original city. Contesting the view that Memphis was just one small area, east of the Saqqara necropolis, this paper will suggest that the urban limits of Old Kingdom Memphis should be extended to include the entire Memphite necropolis.

\section{The History of Memphis}

The history of Memphis is long and complex and has been of interest to scholars for over 2000 years. Volumes have been written about the history and great myths of the city, however the origins as ancient Egypt's capital are still unknown. Traditionally, Memphis was considered a single location, situated east of the Saqqara necropolis (Edwards 1947; Kemp 1989: 36; Verner 2002: 62; Wilkinson 1999: 359), where the remains from the later periods exist today. However, there are several contrasting opinions as to where and how to define the boundaries for this metropolitan area. Earlier scholars suggest that Memphis was at the pyramids of Giza, while others believe that 
Memphis included the area from Giza to Mit Rahina (e.g. Jeffreys 1999). The name, size and location of the ancient capital are examined in this discussion.

Typically, the boundaries of Memphis are defined based on funerary architecture and/or on the extent of the royal necropolis ( $30 \mathrm{~km}$ - from Abu Rowash in the north to Dahshur in the south). Recent investigations into the valley floors around Dahshur, Saqqara, Abusir, Giza and Abu Rowash appear to suggest a larger residential distribution within the region. As this new information is applied to the old paradigm, then perhaps there is evidence supporting a new size and shape for the capital during the Old Kingdom (c.2500 BC).

\section{The Names of Memphis}

One of the more perplexing issues of Memphis is the name itself. 'Memphis' can refer to one of several places, causing confusion and misrepresentation in the academic literature. There are several different uses for the name, each having different, yet specific, geographical references. The name Memphis can refer to either the nome, the royal necropolis, the capital city, the city-centre or the pyramid town of Pepi I.

Egypt was divided into 42 administrative districts, called nomes. The first Lower Egyptian nome was known as Memphis, and its boundaries parallel the distribution of pyramids, from the Abu Rowash pyramid to a little south of Dahshur (Fig. 1-A). The $\mathrm{IV}^{\text {th }}$ Dynasty pyramid at Meidum is not included within these nome boundaries. Also, the Early Dynastic tombs and the Old Kingdom pyramids and private cemeteries are often termed the 'Memphite Necropolis'. The Memphite necropolis stretches for 80 kilometres and is defined by the northern-most pyramid at Abu Rowash and the southern pyramid at Meidum (Fig. 1-B).

'Memphis' can also refer to the capital city, located due east of the Saqqara necropolis. Today, this area is known by its modern Arabic name, Mit Rahina (Fig. 1-C) and is defined by the surviving ancient ruins. The "capital of Memphis" is also referred to as the Ptah temple of Mit Rahina as the city centre, the heart of the social, religious and commercial area (Fig. 1-D). The actual name 'Memphis' is a Greek-derived word, stemming from the hieroglyphic name, $M n-n f r$, after the pyramid town of the $\mathrm{VI}^{\text {th }} \mathrm{Dy}-$ nasty king, Pepi I (Smith and Jeffreys 1986: 88). Gardiner (1947) translates $M n-n f r$ to mean "Pepi is firm[ly established] and well", and believes that $M n-n f r$ was located on the valley floor, at the foot of Pepi's pyramid complex (Figure 1-E).

Thus, there are five different locations for one place-name, Memphis. Just to confuse matters further, there are Early Dynastic jar labels from Abydos (Petrie 1901: pl. XXIII) that refer to the place of 'Memphis' as inbw-hd, or 'White Walls'. It is believed that this is the earliest ancient Egyptian name for the area later known as the capital of Memphis (Edwards 1971). Again, this place-name has no fixed geographical location or archaeological support (contra Lehner 1997; Málek 1997). No archaeological evidence for a white wall has ever been recovered and some, including the present author, doubt that a wall ever existed. The complexity of the name White Walls is a separate discussion in itself and will not be explored further here (see Gardiner 1947; Gauthier 1925-26; Málek 1997; Montet 1957; Sethe 1905). 


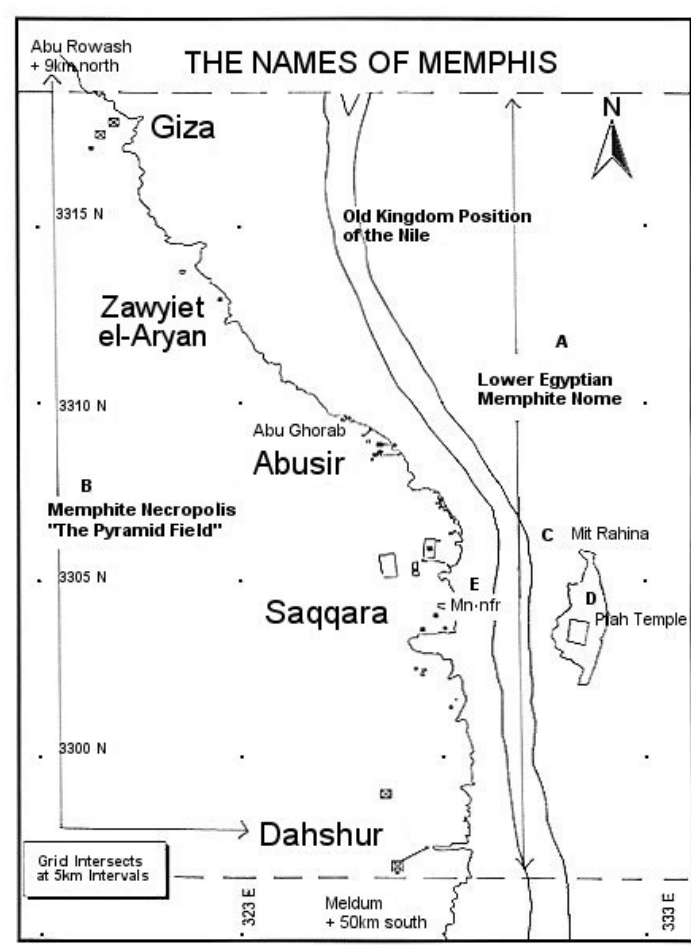

Figure 1. The names of Memphis.

There is no universal agreement regarding the size and location of the Old Kingdom capital. The above discussion illustrates the various ways in which the term 'Memphis' can be misused and misapplied. For example, references to Memphis as the capital city can often refer to both the necropolis and the ruin field, without distinction. It is thus critical to make a distinction between the two areas.

Not only are the terms confused today, but the issue also seemed to have baffled early scholars and explorers. Amongst the great works of the classical historians and geographers, such as Herodotus, Strabo and Diodorus, ancient Memphis was described and documented after the site was abandoned and not during its classical phases. Knowledge regarding the city's origins was obtained through hearsay and contained very little historical truth (Lloyd 1976). However, these sources cannot be ignored, as they are the earliest surviving documents relating to ancient Memphis.

\section{Classical Historians}

The primary historical accounts about the origins of the Egyptian capital are from the Greek writer Herodotus and the Egyptian priest Manetho. Both original accounts date from the Ptolemaic period, with Herodotus writing in $450 \mathrm{BC}$ and Manetho c.323-245 $\mathrm{BC}$. These are the most prevalent of the surviving historical texts that Egyptologists have used to create the foundation upon which modern academic research is based.

The only words that Herodotus writes about the founding of Memphis are as follows:

The priests told me that it was [Menes], the first king of Egypt, who raised the dam which protects Memphis from the floods. On the land which had been drained by the diversion of the river, King [Menes] built the city which is now called Memphis - it lies in the narrow part of Egypt.

(Herodotus II: 99)

The narrowest part of the Nile Valley is the Memphis region, but exactly where its boundaries are remains ambiguous. Herodotus' geographical reference has been interpreted as meaning the apex of the Nile Delta (Lehner 1997; Málek 2000; Verner 
2002), and is assumed at that time to have been in the same location as Mit Rahina is now. Does this vague geographical locale actually refer to the modern ruin field or somewhere else?

Manetho was from the Lower Egyptian nome of Sebennytos, and was a priest of On (Greek Heliopolis) under Ptolemy I and II in the third century BC (Breasted 1905: 14; Emery 1961: 23-4). Manetho's original text, The History of Egypt, was either lost or destroyed (Weigall 1925: 1) and Emery claims that his original writing has only survived "by later writers six hundred years after the author's death with all the resultant corruption through successive copying" (Emery 1961: 24). Manetho's work was later re-recorded by Julius Africanus, a Libyan historian and by Eusebius, Bishop of Ceasarea, in AD 340 (Weigall 1925: 1). It is possible that these later authors may have corrupted, misinterpreted and/or misunderstood Manetho's original work.

Three versions of Manetho's text are presented here (trans. Wadell 1943):

According to Africanus: The first king was Menes, from This, who reigned for 62 years. "He was carried off by a hippopotamus and perished" (29). His son built a palace at Memphis.

According to Eusebius: The first king of the First Dynasty was Menes from This, who ruled for 60 years. "He made a foreign expedition and won renown, but was carried off by a hippopotamus" (31). His son, Athothis, built a palace at Memphis.

The Armenian version of Eusebius: King Menes, from This, "won high renown in the government of his kingdom" (31) and reigned for 30 years. "He was carried off by a hippopotamus god" (33). His son, Athothis "built for himself a palace at Memphis" (33).

The site recorded by Herodotus and Manetho represented the last occupational phase of Memphis, but was this the same site for the city as during the Early Dynastic and Old Kingdom? Every history book found in modern libraries will quote this as an undisputed fact, each author quoting identical primary sources: Herodotus and Manetho. If these sources are critically examined, then perhaps we can gain a different perspective on the location of the ancient capital.

To be fair, neither Herodotus nor Manetho declared Memphis to be the capital. They both agree that, the first king of Egypt, Menes, established a city that was later called Memphis. The rest of their tale is subsequent interpretation from later periods superimposed upon the Early Dynastic and Old Kingdom as possible explanations. Herodotus and Manetho have attempted to explain how Memphis was established and by whom. However, only three 'facts' can be extracted from their accounts: That the first king of Egypt was Menes, that it was Menes who founded Memphis and, that his son, and successor, built a palace at Memphis. 


\section{Early Geographers}

Two of the earliest geographers, Strabo and Diodorus of Sicily, knew the significant relevance of Memphis. These authors made maps of Egypt, featuring three of Egypt's primary ancient cities Alexandria, Memphis and Thebes (Ball 1942: 49).

Strabo wrote Geography, c. $25 \mathrm{BC}$ and noted that Memphis was the royal residence for the Egyptians. Accordingly, Strabo noted that the city was near Babylon "for the distance to [Memphis] from the Delta is only three schoeni" (Strabo 1932: 17). This distance is estimated at 33.36 kilometres (Ball 1942: 11), thus Strabo recorded Memphis as the ruin field of Mit Rahina.

Diodorus described the city as it existed during his lifetime c.59 BC. According to a translation by Oldfather (1956), Diodorus wrote:

Of the descendants of this king, the eighth, known as [Menes], founded Memphis, the most renowned city of Egypt. For he chose the most favourable spot in all the land, where the Nile divides into several branches to form the 'Delta', as it is called from its shape; and the result was that the city, excellently situated as it was at the gates of the Delta, continually controlled the commerce passing into upper Egypt. Now he gave the city a circumference of one hundred and fifty stadia.

(Diodorus I 50: 1-4)

The city's circumference, as described here, is estimated to be $28 \mathrm{~km}$ where one stade is equal to $185.3 \mathrm{~m}$ (Ball 1942: 11). Diodorus is in agreement with the other classical writers regarding Menes and located Memphis at the Delta head.

Both of these early geographers have described and recorded the ruin field of Mit Rahina as 'Memphis'. They agree about its location at the apex of the Delta and describe it as encompassing a large area. It is possible that the city survived as a relic of its earlier size, although the remaining fourth century BC nucleus was at Mit Rahina. However, neither of these writers could attest to the ancient capital's origin.

\section{Historical Accounts}

Accounts from early travellers describe Memphis as a great sprawling metropolis and place it in more than one location. In his PhD thesis, Jeffreys (1999) gives the only account of these early travellers, which is summarised here. Vivant Denon, writing in 1802 , defined the boundaries of the ancient city of Memphis as marked by two pyramid complexes, Giza in the north and Saqqara in the south. Denon was "even inclined towards Giza as the main site" (Jeffreys 1999: 233) for the capital city.

This idea was not exclusive to Denon. During the $18^{\text {th }}$ and $19^{\text {th }}$ centuries, the prevailing idea seems to have been that the boundaries of ancient Memphis included the area of Giza. Other earlier travellers, such as Claude Sicard (1714) and Frederik Norden (1738), describe Giza as the capital (cf. Jeffreys 1999: 68, 70). Perhaps this misconception stemmed from the classical writings of Rufinus, for example, who plotted 
'Memphis' at Giza, on the river bank opposite the Roman fortress of Babylon. Another explanation for the confusion could be the name of a "hamlet, 'Ezbet ('Ali) al-Manf, which is $2.5 \mathrm{~km}$ north of the Khufu pyramid" (Jeffreys 1999: 62), where Manf is an older version of the name Memphis. Although the exact origin of this concept is unknown, its repeated mention cannot be ignored.

Early travellers consistently associated Memphis, the capital city of Egypt, with pyramids. For example, Laurence Aldersey (1586), George Christoff von Neichitz (1636), and Benoit de Maillet (c.1700) each wrote about pyramids in relation to the city of Memphis ( $c f$. Jeffreys 1999: 61-66). Which exact pyramid each were referring to is unknown, as there are over 17 pyramids visible within the boundaries of Memphis. Maillet admits that while the true location of Memphis is unknown, he claims "without the pyramids...we would not know today where that ancient capital of Egypt was" (cf. Jeffreys 1999: 66).

Whether or not this old belief is true or false is arguable. However, the element of significance is the repeated mention of Memphis as being somewhere else, other than at Mit Rahina. Also of interest is the recurrent association of Memphis with Giza, reinforcing the strong relationship between the capital and the pyramids. It seems to provide further justification that Giza may have once been included in the boundaries of the ancient city of Memphis.

The first group to associate the Mit Rahina ruin field with Memphis, the ancient capital city, was Napoleon's expedition in 1798. The collective result of this work was published in Description de l'Egypte, (Néret, reprinted 1997) which became the definitive "truth" about Memphis. However, other contemporary explorers were not as convinced that Memphis was just the six square kilometres of Mit Rahina. Two archaeologists, James Burton and Edward William Lane, both working during the mid1800 s, imagined "that Memphis stretched the whole way up the valley from the Giza pyramids to the Saqqara pyramids" (Jeffreys 1999: 256). Additionally, Lane suggested that Memphis had "suburbs" that reached as far north as Giza and beyond Mit Rahina in the south (Jeffreys 1999: 97).

\section{Re-Locating Memphis}

One possible reason that Mit Rahina was typically considered the location for ancient Memphis is because it has the greatest density of pharaonic remains. The majority of these finds are large scale, monumental architecture which date from the Middle Kingdom onwards and were in use concurrent with several re-use phases of Saqqara as a sacred burial ground. The earlier Old Kingdom sites of "greater Memphis", such as Abu Rowash, Giza and Abusir, were not subject to this sort of re-occupation. With the collapse of the Old Kingdom, the surviving pyramid towns fell into disuse and eventual abandonment, with the exception of $M n-n f r$, the pyramid town of Pepi I. In contrast, Mit Rahina was subjected to several phases of construction and re-occupation that continued until Roman times. This process added to the already growing density of burials and temple structures in the immediate area, while neglecting the remainder of the Memphite region. Thus, it becomes easier to understand how the apparent as- 
sociation between 'Memphis' and Mit Rahina came into being, rather than evaluating the entire region as a whole.

In light of the historical discussion of Memphis, perhaps it can now be reconsidered and re-evaluated in terms of its size and boundaries. All of the above suggestions illustrate a different perception of the ancient city. If boundaries are pushed beyond the six square kilmotre area of Mit Rahina to include the entire necropolis, it then seems possible that Memphis was a narrow, yet extensive settlement, extending the entire 30 kilometre length of the Memphite necropolis.

However, this idea about the size of Memphis is not original nor is it entirely new. An Egyptian historian, $c .1400 \mathrm{BC}$, documented the size of ancient Memphis as " 30 miles long by 20 miles wide" ( $c f$. Jeffreys 1999: 58). Similarly, Sir Henry Blount (Blout 1794) and James Burton (1822) both recorded Memphis as being twenty by thirty miles long ( $c f$. Jeffreys 1999: 92). Denon (1799) related the size of the Memphite necropolis to the size of the ancient city (cf. Jeffreys 1999: 85). Finally, an early Egyptologist, John Gardner Wilkinson $(1822,1842,1855)$ recorded Memphis as 17 English miles by 6 miles in area (cf. Jeffreys 1999: 98).

The idea about Memphis being larger than the Mit Rahina ruin field is not an opinion exclusive to early travellers and explorers. Several $20^{\text {th }}$ century authors also share this belief. Petrie (1909: 2) compared Memphis with the various towns and villages of London, by suggesting that Memphis was a large zone filled with gardens and fields that had agglomerated together to create a large city. Lampl (1981:26) uses the term "greater Memphis" in reference to the Old Kingdom royal necropolis. Furthermore, Jeffreys (2000: 24) mentions that during the period of peak political importance, "Memphis was a vast metropolis that stretched at least $10 \mathrm{~km}$ from north to south". So perhaps Memphis can now be regarded as a sprawling urban area of large and small towns and villages (Brewer and Teeter 1999: 53), extending for over 30km (Málek 1983: 27).

\section{Settlement Archaeology}

Recent settlement work done in this region further supports the proposal that Memphis was significantly larger than previously believed. Typically, the majority of available information about Memphis has been obtained from the Memphite necropolis and not from the ruin field. This is a reflection of the early intellectual orientation of Egyptology that dismissed settlement remains in favour of philology, art history and mortuary remains (Adams 1997). Yet, the most incongruent 'fact' regarding Memphis is the scant archaeological material to support over 1000 years of continued occupation (c.3100-2100 BC). If Memphis was indeed the Old Kingdom capital city, then it follows that some archaeology should have survived.

A distribution map of Old Kingdom finds (Fig. 2) illustrates that hardly a trace of archaeological material has survived in the ruin field of Mit Rahina from this formative period. Of that which has been recovered, the majority has lost its original provenience. In the flood plain areas surrounding Mit Rahina, the lack of remains is unsurprising considering the mud-brick and mostly organic nature of the building materials of 


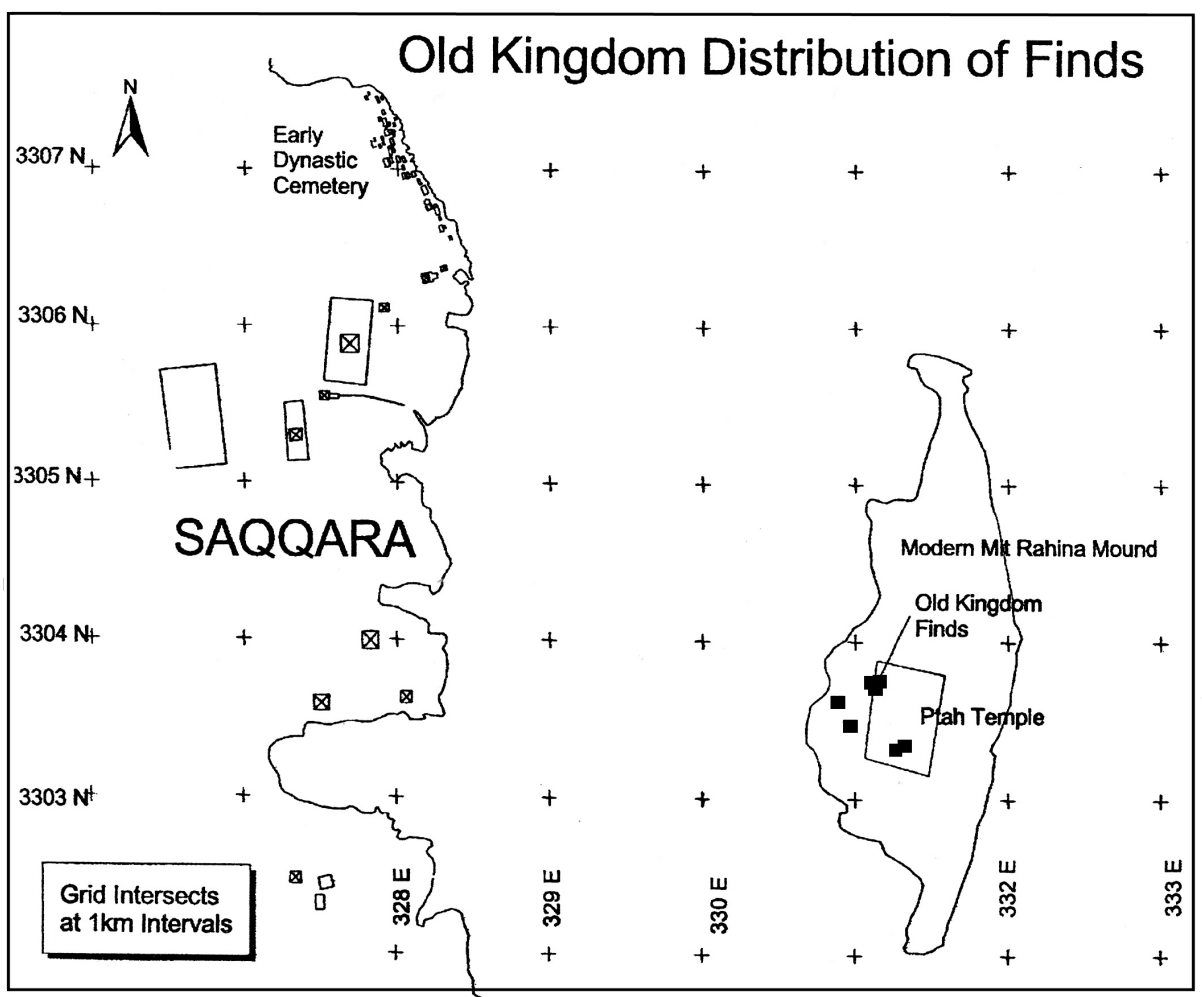

Figure 2. Distribution map of Old Kingdom finds: data from the Survey of Memphis (Jeffreys 1985).

domestic structures and the rate of sediment accumulation from the annual inundation. But how could a city that was theoretically occupied for over 1000 years not leave any archaeological traces? The missing archaeology, considering the inherent research bias of archaeologists, can be attributed to several factors such as the changing course of the Nile, the possibility that material has not yet been discovered, or that the archaeology simply is not there.

First, the rate of sediment accumulation in the valley floor of the Memphite region is estimated at one metre per millennia (Butzer 1976; Hassan 1993). This would place a second millennia $\mathrm{BC}$ settlement several metres below the modern ground surface. Jeffreys (1997) estimates that the Old Kingdom ground level is four metres below the area west of Mit Rahina. Sediment accumulation has rendered traditional excavation techniques both inefficient and ineffective. Second, the construction of the Aswan dam in 1968 has created a shallow water table that has possibly waterlogged everything $50 \mathrm{~cm}$ below the current ground surface.

Another element affecting the potential for archaeological recovery is the shift in the river's course. Collected sediment samples have determined that the position of the Nile during the Old Kingdom was several kilometres west of its present location; closer 
to the desert edge (Jeffreys and Tavares 1994; Jones 1995). It has been observed that there was a gradual eastward movement of the Nile, where the Nile itself had probably existed to the west of Mit Rahina during the Old Kingdom (Giddy 1993; Smith et al. 1983). Jeffreys (2000: 25-6) believes that the absence of settlement remains of the Early Dynastic and Old Kingdom may be a result of erosion and sediment accumulation. It is possible that the progression of the river may have erased a significant portion of these early settlements (Giddy 1993). Therefore, any occupation along the edge of the Saqqara-Abusir escarpment may have been scoured out by a shift in the watercourse (Giddy et al. 1990: 12). The reconstruction of the Nile in this location would put any potential settlements in one of two locations; either along a very narrow strip of land (estimated less than two kilometres) between the western desert escarpment and the west bank of the Nile or clear on the other side of the Nile, to the east. With the Nile's gradual eastward movement, any material to the east will have been completely eradicated.

Even though several later period occupation sites have been located in the region, there is next to no in situ Early Dynastic or Old Kingdom material at Memphis (Giddy 1993: 193). One explanation for this may be the sebakh-diggers, who have been using ancient mud-bricks as fertiliser on their fields for centuries. This destructive practice has lead Kemp (1976: 27) to conclude that lack of surviving evidence "implies that it may have been cleared away by [modern] sebakh-digging". There is also the possibility that any Early Dynastic material southwest of Mit Rahina was contaminated or destroyed by subsequent occupation during later periods (Giddy et al. 1990: 13).

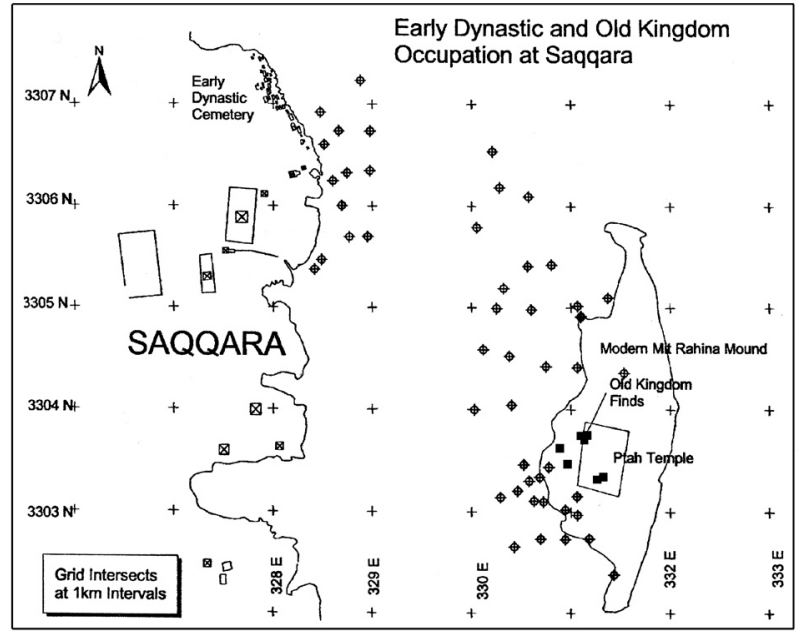

Figure 3. Distribution of drill cores in and around Mit Rahina: the symbols represent individual drill cores that are positive indicators of occupation, (after Jeffreys and Tavares 1994).
Despite these obstacles, some fragmentary settlement evidence has survived. The London-based Egypt Exploration Society (EES) has been conducting a "Survey of Memphis" employing an alternative recovery technique, namely drill cores (or manual hand auger), to access and retrieve buried deposits. Working since 1985, the EES team has successfully employed drill cores throughout the Mit Rahina area (Fig. 3), enabling them to reasonably locate and assess early settlements (Giddy and Jeffreys 1991; Giddy et al. 1990: 12-13). 
The drill core recovery technique has been used successfully in the Nile valley to identify and locate early settlements. Other settlement areas have been recovered as a result of urban expansion. Thus far, Early Dynastic material has been found at Abusir and four Old Kingdom settlements located at Abu Rowash, Giza, Saqqara and Dahshur. The site that has yielded the greatest amount of structural information is Giza, in an area southwest of the Sphinx. This industrial site was located on the desert plateau and not on the valley floor, which has largely contributed to the preservation and recovery of the architecture. Each of these settlements are located in the boundaries of the Memphite region and were occupied during different phases of the Old Kingdom.

\section{Residential Memphis}

Perhaps Memphis was not one large city, but a dispersed urban conglomerate that extended throughout the entire region. Lehner $(1997: 7,15)$ suggests that the Memphite necropolis was a "capital zone" and the capital was a cluster that included most of the Old Kingdom pyramids. Lehner's remarks echo the earlier notions associating pyramids with the capital city. Jeffreys and Tavares (1994: 151) have noted that the changing pattern of tomb distribution during may indicate a change in the centre of the capital city, yet remaining within the regional boundaries. It is very possible that the narrow and constricting topography of the Memphis region dictated settlement placement (Málek 1997: 94). Thus instead of the city developing around a central, fixed point, urban growth was linear, parallel with the desert escarpment and the Nile.

\section{Abu Rowash}

An Old Kingdom settlement was found four kilometres north of Abu Rowash and six kilometres southwest of the modern village of Asuim. A 1992 salvage trench excavation along the Baraket Drain Channel "cut through the upper part of a considerable mound of in situ Old Kingdom settlement debris" (Jones 1995: 94). There is possible evidence for industrial work or production with traces of carnelian, quartzite grinding stones and basalt hammer stones. The settlement evidence comes from collapsed mudbrick walls with ashy layers containing ceramics. Jones reports that this "evidence pointed to concentrated activity during the Old Kingdom" (Jones 1995: 96). This settlement is believed to be isolated to the Old Kingdom with an absence of any earlier or later period materials.

The most impressive element to this site is the density of remains. Old Kingdom material was found to be over $6.5 \mathrm{~m}$ thick, ranging in depth from $18.31-14.85 \mathrm{~m}$ above sea level, extending for over 100m. Jones (1995: 92) concludes, "the findings in these borings were sufficient to indicate the presence of an in situ occupation". The recovered material is believed to represent a fraction of the site in its entirety, as it is possible that there was a larger spread of occupation in the immediate vicinity of the pyramid complex valley floor.

\section{Giza}

The largest and most comprehensive Old Kingdom site found to date is at Giza. Results from trench excavations and drill cores from the wastewater project (Jones 1995) imply that Giza was more than just a mortuary complex. A possible three square kilometre 
Old Kingdom settlement site has been postulated upon the evidence of a broad scatter of residential debris (Hawass 1996; Hawass and Lehner 1997; Jones 1995). This includes domestic ceramics and animal bones (some burnt fragments and others with butchery marks), ashy/charcoal pieces and mud brick architecture (Hawass 1996: 58). Archaeological soils were consistently found in borings between a depth of three and six metres below the modern ground surface, within a three square kilometre area. Hawass suggests that there is "a continuous spread of early settlement remains" (1996: 57) east of the Giza pyramids.

A large limestone wall located to the southeast (178m long and 7-7.5m thick), Heit el-Ghorab or the 'Wall of the Crow', physically separates the royal mortuary complex from the sedentary living quarters of a socially segregated settlement. This area extends for two square kilometres and includes a workers' camp, the artisans' village, their cemeteries and an industrial area (Hawass 1996; Lehner 1985). Lehner has suggested that the settlement areas might have been the largest known during the Old Kingdom, "solely in terms of area" (Lehner 1985: 135). There are two socially distinct areas, based on the size of the housing units. The workers' quarters are small units measuring four by five metres, while the other "officials" houses are larger and have more space between the units (Lehner 1985: 135).

The industrial, or institutional, area has elements of a bakery, brewery, winery, possible fish and meat preparation area, copper workshop, pottery factories, pigment preparation workshop and faience factory (Hawass 1996: 60; Lehner 1985, 1999). This is the proposed area from which the construction supplies originated and food was prepared to support the workers. Evidence of large-scale, long-term industrial production advocates an extensive, sedentary workforce.

\section{Abusir}

The EES is now able to suggest that an Early Dynastic occupation site existed slightly north of the modern ruin field that followed the Saqqara-Abusir escarpment. Enough Early Dynastic pottery has been recovered to allow Jeffreys to "predict with reasonable confidence that unmixed deposits of this date... lie directly over archaeologically sterile clays which run up to the cliff face" (Jeffreys 1997: 2). The drill core results indicate that an Early Dynastic site would have been confined to the west and opened up to the northwest of the modern Mit Rahina ruin field (Giddy, 1993: 194; Giddy and Jeffreys 1991: 6). By predicting the location for the Old Kingdom Nile, Jeffreys and Tavares (1994: 159) have concluded that an early settlement would have been defined by the topography; the desert to the west and the Nile to the east. Any settlements would then have to be somewhere in between. Jeffreys (2000: 26) mentions that the Early Dynastic town was located closer to the elite tombs at north Saqqara, thus placing a settlement just south of the Abusir pyramid complex (Wilkinson 1999: 243). This Early Dynastic site lies on the valley floor between the First and Second Dynastic cemetery of north Saqqara (Giddy et al. 1990: 13; Giddy and Jeffreys 1991: 6). It is now possible to conclude, with some certainty, that a relatively large settlement was present during the Early Dynastic period parallel to the Saqqara-Abusir escarpment. 


\section{Saqqara}

The material recovered from Saqqara has come from the west of the modern ruin field, in a long, thin band parallel to the desert escarpment. Jones (1995: 98) has mentioned that in results from borings and open-cut trenches north of Saqqara "Old Kingdom material is found everywhere". Drill cores recovered from the west, southwest and northwest of Mit Rahina revealed Early Dynastic and Old Kingdom ceramic sherds (Giddy et al. 1990: 12). The most extensive early remains are from Kom el-Fakhry (Jeffreys and Tavares 1994: 154), immediately south of Mit Rahina and directly east of the pyramids of Pepi I, Merenre and Djedkare (Giddy 1993: 193). Gardiner (1947: 122) believes that the Old Kingdom town of Pepi I, Mn-nfr, was located $2.5-3 \mathrm{~km}$ west of Mit Rahina, at the foot of the pyramid. This belief corresponds precisely with the findings at Kom el-Fakhry. Kemp (1976: 26) also predicted that an Old Kingdom town is under the modern Kom el-Fakhry. Giddy (1993: 193) postulates that an Old Kingdom settlement lies under the Middle and New Kingdom structures. Furthermore, Jeffreys and Tavares (1994: 159) propose a VI ${ }^{\text {th }}$ Dynasty settlement under the First Intermediate Period cemetery at Kom el-Fakhry because the ground is " 3 metres higher than the Ramesside ground level a little to the east". Drill core testing has revealed the Ramesside temple to have been built on culturally sterile deposits.

\section{Dahshur}

Drill core work in the alluvial plain of Dahshur, conducted by the German Institute in Cairo, has found Old Kingdom material in the area of Snefru's "Red" pyramid valley temple (Alexanian and Seidlmayer 2000, 2002a, 2002b). Limestone chips, mud-brick architecture, and rubbish deposits were recovered from 15 drill cores, thus confirming the location of the pyramid town. The area is believed to have been occupied from the IV ${ }^{\text {th }}$ Dynasty with a surface area of at least $200 \times 130 \mathrm{~m}$. The level from which this material was recovered is approximately four to six metres below the modern surface and $3.5 \mathrm{~m}$ thick, under lenses of sterile desert sands. This stratum corresponds with the Old Kingdom levels recorded elsewhere in the region.

\section{Conclusion}

The classical and historical writers had conflicting views about what constituted Memphis. However, they all seem to agree on one thing; that pyramids are indivisible from the ancient capital city. One might even go so far to say that the Old Kingdom pyramids define the boundaries of the city. The settlement evidence concurs with this suggestion as the occupational distribution parallels the Old Kingdom pyramids. Occupational sites at Abu Rowash, Giza, Abusir, Saqqara and Dahshur are each located away from the traditional 'Memphis' of Mit Rahina. Each occupational area is located in conjunction with a royal cemetery, seemingly connecting settlements and pyramids. This material appears to support Lehner's hypothesis of a "capital zone" (Lehner 1997: 7, 15). If this region was reconsidered as such, then perhaps the capital of Memphis constantly moved or the evidence has created a new manifestation for Memphis (Fig. 4).

Perhaps now Memphis may be considered a dynamic urban centre. It is possible that Old Kingdom Memphis was not confined to one small, nucleated settlement area but rather extended throughout the entire Memphite region. Jeffreys and Tavares (1994: 


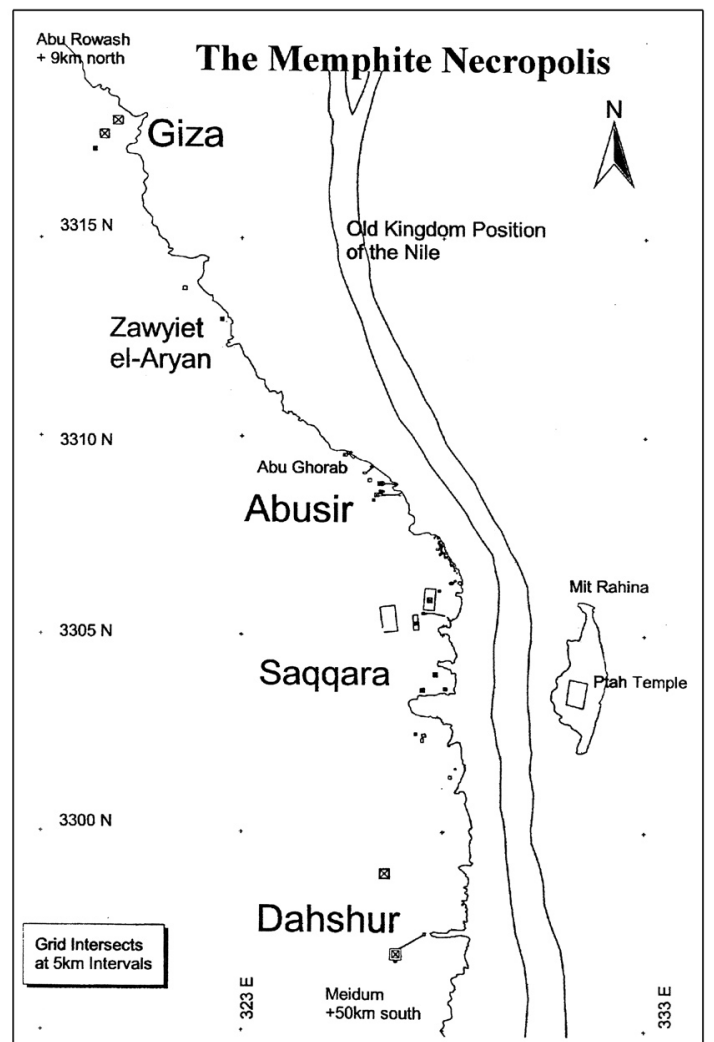

Figure 4. A new Memphis?
159) suggest that Old Kingdom occupation was basically a ribbon development along the western bank of the Nile, parallel to the necropolis. Furthermore, Jeffreys proposes that Memphis should not be considered as a concentrated area of dense occupation, but rather suggests "straggling ribbon developments along abandoned levees and active riverbanks, all being seasonally active under flood conditions but less intensively occupied during other times of year" (Jeffreys 1999: 255). Maybe now Memphis can be redefined as a long and narrow residential zone, constrained by the desert ridge on the west and the Nile on the east. Therefore, if we consider Memphis as a $30 \mathrm{~km}$ area, and not as one specific site, such as Mit Rahina, then the capital of 'Memphis' could actually refer to the entire Memphite region. It can even be argued that the divisions between these sites, Abu Rowash, Giza, Abusir, Saqqara and

Dahshur, is a creation of modern archaeologists and may not have been the view held by the ancient Egyptians (Málek 2000: 108). Thus, if the Memphite region is viewed as one site as a whole and not through its representational parts, then perhaps it is a more accurate description of Memphis.

\section{Acknowledgements}

I would like to thank the PIA editorial staff, especially Julie Eklund and Steve Townend, for encouraging me to write this paper. I am grateful for the assistance and supervision of Dr. David Jeffreys with this research, conducted under his direction at the Institute of Archaeology, University College London. I am deeply indebted to Dr. Mark Lehner for allowing me unrestricted access to the Giza material and for supporting a drill core survey of the Giza settlement area. All maps in this paper are by the author.

\section{References}

Adams, M. 1997. A Textual Window in the Settlement Alexanian, N. and Seidlmayer, S. 2000. Die NecropoSystem in Ancient Egypt, in Lusting, J. (ed.) Anthropology and Egyptology: A Developing Dialogue. Sheffield: Sheffield Academic Press, 90-105. le von Dahschur. Forschungsgeschichte und Perspektiven, in Barta, M. and Krejci, J. (eds.) Abusir and Saqqara in the Year 2000. Prague: Academy of Sciences of the Czech Republic, 283-304. 
Alexanian, N. and Seidlmayer, S. 2002a. Die Giddy, L., Jeffreys, D. and Málek, J. 1990. Memphis, Residenznekropole von Dahschur Erster Grabungsbericht. Mitteilungen des Deutschen Archäologischen Instituts, Kairo 58, 1-28.

Alexanian, N. and Seidlmayer, S. 2002b. Survey and Excavations at Dahshur. Egyptian Archaeology 20, 3-5.

Ball, J. 1942. Egypt in the Classical Geographers. Cairo: Government Press. 1989. Journal of Egyptian Archaeology 76, 1-16.

Hassan, F. 1993. Town and Village in Ancient Egypt: Ecology, Society and Urbanisation, in Shaw, T., Sinclair, P., Andah, B. and Okpoko, A. (eds.) The Archaeology of Africa: Food, Metals and Towns. London: Routledge, 551-569.

Breasted, J. H. 1905. A History of Egypt. New York: Charles Scribner's Sons.

Hawass, Z. 1996. The Workmen's Community at Giza, in Bietak, M. (ed.) Haus und Palast im Alten Ägypten. Wien: Verlang der Osterriechischen Akademie der Wissenschaften, 53-67.

Brewer, D. and Teeter, E. 1999. Egypt and the Egyptians. Cambridge: Cambridge University Press.

Hawass, Z. and Lehner, M. 1997. Tombs of the Pyramid Builders. Archaeology 50(1), 39-43.

Butzer, K. 1976. Early Hydraulic Civilization in Egypt. Chicago: University of Chicago Press.

Herodotus 1948. The Histories I (trans. de Selincourt, A.). Baltimore: Penguin Books.

Diodorus 1956. Diodorus of Sicily, IV (trans. Old- Jeffreys, D. 1997. Excavation and Survey East of the father, C. H.) London: William Heinemann, Ltd. Saqqara-Abusir Escarpment. Journal of Egyptian Archaeology 83, 2-4.

Edwards, I. E. S. 1947. The Pyramids of Egypt. Mid- Jeffreys, D. 1999. Written and Graphic Sources for dlesex: Pelican Books. an Archaeological Survey of Memphis, Egypt: from $500 \mathrm{BCE}$ to $1900 \mathrm{CE}$, With Special Reference to the Papers of Joseph Hekekyan. Unpublished $\mathrm{PhD}$ Thesis, Institute of Archaeology, University College London. J. and Hammond, N. G. L. (eds.) The Cambridge Ancient History. Cambridge: Cambridge University Press, 1-17.

Jeffreys, D. 2000. Investigating Ancient Memphis, Pharaonic Egypt's Northern Capital. Archaeology International 3, 24-27.

Emery, W. B. 1961. Archaic Egypt. Middlesex: Penguin Books.

D. and Tavares, A. 1994. The Historic Landscape of Early Dynastic Memphis. Mitteilungen des Deutschen Archäologischen Instituts, Kairo 50, 143-173.

Gauthier, H. 1925-26. Dictionnaire des Nomes Géographiques Contenus dans les Textes Hiéroglyphiques I(III). Cairo: Jones, M. 1995. A New Old Kingdom Settlement L'Institut Français D'Archaéologie Orientale. Near Aussim: Report of the Archaeological Discoveries Made in the Barakat Drain Improvement. Mitteilungen des Deutschen Archäologischen Instituts, Kairo 51, 85-98.

Giddy, L. 1993. Memphis and Saqqara During the Late Old Kingdom, in d'Étude, B. (ed.) Hommages à Jean Leclant. Cairo: Institut Français d'Archéologie Kemp, B. 1976. A Note on Stratigraphy at Memphis. Orientale, 189-200.

Journal of the American Research Centre in Egypt 13, 25-29.

Giddy, L. and Jeffreys, D. 1991. Memphis, 1990. Journal of Egyptian Archaeology 77, Kemp, B. 1989. Ancient Egypt: Anatomy of a Civili1-6. zation. London: Routledge. 
Lampl, P. 1981. Cities and Planning in the Ancient Montet, P. 1957. Geographie de l'Egypte Ancienne. Near East. London: Studio Vista.

Paris: Imprimerie Nationale.

Lehner, M. 1985. The Development of the Giza Néret, G. 1997. Description de l'Egypte. Cairo: Necropolis: The Khufu Project. American University in Cairo Press. Mitteilungen des Deutschen Archäologischen Instituts, Kairo 41, Petrie, W. M. F. 1901. The Royal Tombs of the 109-143. Earliest Dynasties 2. London: The Egypt Exploration Fund.

Lehner, M. 1997. The Complete Pyramids. London: Thames and Hudson.

Petrie, W. M. F. 1909. Memphis I. London: School of Archaeology in Egypt and Bernard Quaritch.

Lehner, M. 1999. The Millennium Project: Marathon Excavation to 'Capture' Area A. AERAgram: Newsletter of the Ancient Egypt Sethe, K. 1905. Untersuchungen zur Geschichte und Research Associates 3(1), 1-3. Altertumskunde Aegyptens. Leipzig: J. C. Hinrichs'sche Buchhandlung.

Lloyd, A. 1976. Herodotus Book II Commentary 198. Leiden: E.J. Brill.

Smith, H. and Jeffreys, D. 1986. A Survey of Memphis, Egypt. Antiquity 60, 88-95.

Málek, J. 1983. Giza, in Smith, H. S. and Hall, R. (eds.) Ancient Centres of Egyptian Civi- Smith, H., Jeffreys, D. and Málek, J. 1983. The lization. London: IMPADS, 25-36. Survey of Memphis, 1981. Journal of Egyptian Archaeology 69, 30-42.

Málek, J. 1997. The Temples at Memphis. Problems Highlighted by the EES Survey, in Strabo 1932. The Geography of Strabo, VIII. (trans. Quirke, S. (ed.) The Temple in Ancient Egypt: New Discoveries and Recent Research. London: British Museum Press, 90-101. Jones, H. L.). London: William Heinemann Ltd.

Verner, M. 2002. The Pyramids: Their Archaeology and History. (trans. Rendall, S.). London: Atlantic Books.

Málek, J. 2000. The Old Kingdom, in Shaw, I. (ed.) The Oxford History of Ancient Egypt. Oxford: Oxford University Press, 89- Weigall, A. 1925. A History of the Pharaohs I. Lon117. don: Thornton Butterworth, LTD.

Manetho 1943. Manetho (trans. Waddell, W. G.) Lon- Wilkinson, T. 1999. Early Dynastic Egypt. London: don: William Heinemann Ltd. Routledge. 